\title{
Fraud in Sharia Rural Bank: How It Affects Their Roles in Assisting Micro Small Medium Enterprise in Indonesia
}

\author{
Yusmansyah $^{1}$, Nafsiah Mohamed ${ }^{2},{\text { Farah } \text { Aida }^{3} \text {, Wiwik Utami }}^{4}$ \\ \{yusman1957@gmail.com¹, nafsiah793@uitm.edu.my², aidanadzri@uitm.my.edu³,wiwikutami@gmail.com ${ }^{4}$ \} \\ Institute of Digital Business, Indonesia ${ }^{1}$, Universiti Teknologi MARA, Shah Alam, Selangor Darul Ehsan, Malaysia \\ $40450^{2,3}$, Mercu Buana University, Indonesia ${ }^{4}$
}

\begin{abstract}
This concept paper studies fraud in Sharia Rural Bank and how it affects their roles in assisting Micro Small Medium Enterprises (MSMEs). The study reviews the literature on the history of fraud in Sharia Rural Bank. This paper explores previous research and court cases on fraud in sharia rural banks. All these information was collected from journal articles, conference proceedings, newspaper, books and internet search related to this issue. It was found that Sharia Rural Bank play important role in assisting MSMEs however there were a lot of issues found such as miss interpretation in carrying out the sharia principle that affect their roles in helping MSMEs. Therefore, this paper suggests good corporate governance is vital to ensure the fraud risk is minimized, thus improving their effectiveness in assisting MSMEs in Indonesia.
\end{abstract}

Keywords: fraud, sharia rural bank, micro small medium enterprises

\section{Introduction}

Indonesia is a country with a lot of diversity, both conventional and Islamic microfinance, the former evolving over a period of over one hundred years, preceded by a history of informal finance of unknown differentiated microfinance infrastructures in the developing world. Comprising some six thousand formal and 48 thousand semiformal registered microfinance units serving about 45 million depositors and 32 million borrowers, eight hundred million channelling groups, and millions of informal financial institutions and self-help groups. There is hardly an institutional type of microfinance that is not found in Indonesia.

One of the microfinance institutions in Indonesia is Sharia Rural Banks (BPR Sharia). The establishment of Sharia Rural Banks in Indonesia is deeply connected to the establishment of Rural Banks. BPR whose legal status is authorized through the Monetary and Banking Financial Policy Package (PAKTO dated October 27, 1998, is essentially a modification (new model) of Lumbung Desa and Bank Desa which have existed since the 1980s. BPRS was first established in October 8, 1990, in Indonesia after obtaining the principal license from the Minister of Finance of the Republic of Indonesia. It opened its doors and began operating on August 19, 1991. The first group of established Sharia BPR were PT. BPRS Dana Mardhatillah, kec. Margahayu, Bandung, PT. BPRS Berkah Amal Sejahtera, Bandung, and PT. BPRS Amanah Rabbaniyah, Bandung. The establishment of BPRS was seen as an active step in restructuring the economic framework of country, as outlined in the various financial policy, monetary and banking packages in general.

The establishment of Sharia Rural Banks in Indonesia is based on the demands of Islamic friendship which is a strong desire of most Muslims in Indonesia, as well as an active step in order to fill the opportunity against the policy that frees the bank in determining the interest rate, which is then known as interest-free banks in particular. Act No. 10 of 1998 which amends Law Number 7 of 1992 concerning Banking seems clear and firmly recognizes the status of Sharia banking, as mentioned in article 13, Rural Bank Enterprises.

Article 13 letter $\mathrm{C}$ reads as follows: Provides financing and placement of funds under the principle of Sharia, in accordance with the provisions stipulated by the Bank of Indonesia. The existence of Sharia Rural Banks is specifically spelled out in the form of Decree of the Board of Directors of BI. 32/34 / Decree / Dir, dated May 12, 1999, concerning Commercial Banks based on the Sharia Principles and Decree of the Board of Directors of BI. 32/36 / Decree / Dir, dated May 12, 1999, and Circular Letter No. BI. 32/4 / KPPB dated May 12, 1999, on the People's Credit Bank Based on the Sharia Principles. 
Generally, the purposes of the establishment of Sharia Rural Banks are as follows: (1) Improving the economic welfare of the Islamic ummah, especially the weak economic class society in general in rural areas; (2) Increase employment, especially at the sub-district level to reduce the flow of urbanization; (3) To foster the spirit of ukhuwahislamiyyah through economic activities to increase per capita income towards an adequate quality of life.

Objectives for establishing Sharia BPRs in the economy, accelerate the rotation of economic activity because the real sector will get funding especially MSMEs (Rodoni and Hamid, 2008).

Thus, Sharia Rural Banks (hereafter BPRS) can participate in mobilizing capital for development purposes and also to educate the people in saving; by providing a close, safe and easy place to save money for small savers.

From the objectives mentioned above, it is known that BPRS has a role in empowering people's economy by developing weak economic groups such as MSMEs. This is reinforced with data from sharia banking (2016), BPRS focuses to serve the Micro and Small Business sector (hereafter MSEs) that distinguishes themselves with Commercial Banks / Sharia Commercial Banks that focus on medium and large-scale financing. As shown in Figure 1, it appears that the financing disbursed by the BPRS for MSEs is greateras compared to other sectors. Unlike the Sharia Commercial Bank and Sharia Business Unit, the amount of financing is larger for sectors other than small and medium BPRS becomes an alternative to conventional financial institutions, especially on a small-scale, in developing the economic sector in the financing of MSMEs. Based on statistical data of Sharia banking as at December 2015, the distribution of BPRS financing to MSMEs reached Rp.3.377 trillion. This number continues to increase year by year. In the next period per December 2017, the distribution of BPRS financing to MSMEs reached Rp.7.00 trillion.

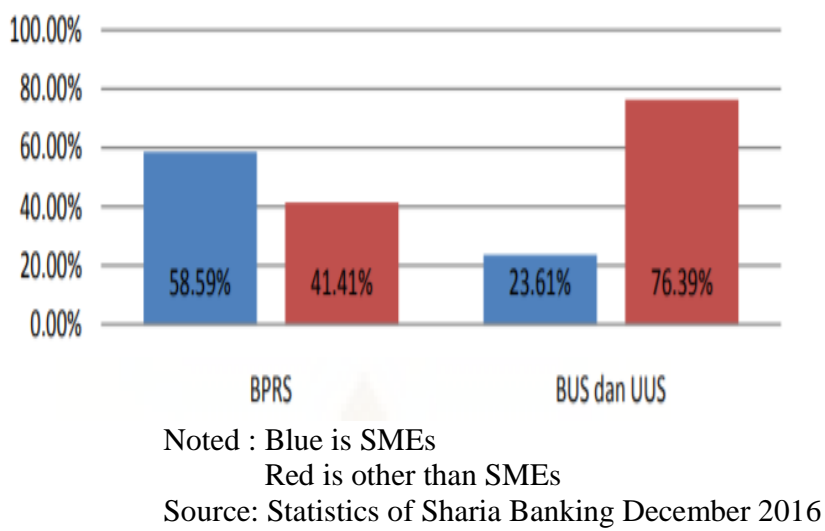

Figure 1. Financing of Sharia Banking by Financing Group

Fraud according to the Association of Certified Fraud Examiner (ACFE, 2016) establishes as an action that receives benefits, in a way that is not by following the rules and is unpredictable, deceitful, cunning, and dishonest which can be detrimental to others.

Bank Indonesia circular letter No. 13/28/DPNP referred to as Fraud is an act of deviation or omission that is intentionally carried out to deceive, cheat, or manipulate banks, customers, or other parties that occur in the bank and/or use bank facilities resulting in banks, customers, or other parties suffer losses and/or fraud perpetrators benefit both directly and indirectly.

The definition of micro-enterprises can be defined from the definition of MSMEs itself, which in Indonesia is different. Among them is the Central Bureau of Statistics (BPS), and Law No. 20 the Year 2008. Central Bureau of Statistics defines MSMEs based on the quantity of labour. Micro, Small-scale business is a business entity that has a workforce of 1-5, and 6-19 people, while medium-sized businesses are business entities that have a workforce of 20-99 people.

\section{Literature Review}




\subsection{Fraud In Islamic Bank}

The ACFE research results outlined in the report to nations on occupational fraud and abuse (2016) state that the banking and financial services sector has the highest fraud rate of $17.8 \%$ of the total $20 \%$. In practice, the existence of sharia elements does not guarantee an institution is free from fraud or commonly called fraud. This can be seen in cases of fraud that occur in sharia institutions. Like the case in Bank Syariah Mandiri (BSM) which involved internal banks, namely fictional lending to BSM Bogor Branch (Rahman, 2013).

Bank Syariah Mandiri was hit by a case of fraud which was arguably the most primitive of fictitious credit by falsifying key documents, with potential losses reaching Rp102 billion. BSM has fired three of its officials who have been proven to be involved in the distribution of fictitious loans for land purchases and housing development in the Bogor area, namely the Head of the Bank Syariah Mandiri Bogor Main Branch, the Head of the Bank Syariah Mandiri Bogor Supporting Branch, and the Bank Syariah Mandiri Bogor Accounting Officer.

Another case in one of the Sharia Banks, in November 2014, based on internal audit findings and also the implementation of Good Corporate Governance (GCG) carried out a despicable act of embezzlement which was then handed over to the Metro Police at a potential loss of Rp.75 billion.

In addition to sharia compliance, the application of good corporate governance (GCG) has been proven to improve the reputation and trust of the people in Islamic banks. According to Capra, Ahmad, and Habib (2002), failure in applying sharia principles will make customers move to another bank by $85 \%$.

Theoretically, the practice of good corporate governance can improve company performance, reduce risks that may be carried out by the board with its own favorable decisions and generally good corporate governance can increase investor confidence to invest capital which has an impact on performance (Ristifani, 2009).

\subsection{Fraud in BPR and BPRS}

The Financial Services Authority (OJK) states that the most vulnerable banking crimes occur in Rural Banks (BPR) and Sharia Rural Banks compared to commercial banks. Executive Head of OJK Banking Supervisor said, the number of BPRs and BPRS as many as 1,800 banks compared to the number of commercial banks, which were only 118 banks, certainly made the opportunity for more 'fraud' to occur in BPR and BPRS. "Banking crimes mostly occur at BPR and BPRS. Around 80 percent of BPRs and BPRS are closed because of fraud,"

The Financial Services Authority (OJK) revealed a case of Banking Crimes conducted by the Managing Director of BPR KS Bali Agung Sedana, related to granting loans to 54 debtors with a value of Rp.24,225 billion which was not in accordance with procedures. The modus operandi is to order BPR employees to process loans to 54 debtors with a total value of Rp.24,225 billion in the March-December 2014 period, not in accordance with procedures leading to false records. The case file was submitted to the Public Prosecutor of the Denpasar Bali District Court. OJK through the Decision of the Board of Commissioners (KDK) Number KEP-202 / D.03 / 2017 concerning Revocation of Business License of PT Bali Rural Credit Bank Agung Sedana, revoked the business license of PT Bali Rural Credit Bank Agung Sedana, having its address at Jalan Raya Kerobokan Number 15Z, Kuta, Badung Bali as of 3 November 2017. The BPR has entered the status of the Bank under Special Supervision since 12 April 2017.

The Financial Services Authority uncovered a case of Banking Crimes committed by the BPR Multi Artha Mas Sejahtera Commissioner with a value of Rp 6,280 billion used for personal interests, the modus operandi carried out with false records in the books or in the reporting process, or in documents or reports on business activities. Submit Case Files to Bekasi District Court Public Prosecutors.

PT. Bank Perkreditan Rakyat Multi Artha Mas Sejahtera, having its address at Revo Town (formerly Bekasi Square Shopping Center) Number 78, Pekayon Jaya, Bekasi City has been revoked by OJK since two years ago, namely since August 26, 2016.

The Financial Services Authority (OJK) has handled cases of alleged banking crime by the former head of PT BPRS Al Hidayah Pandaan, Pasuruan Regency and has been handled by the legal apparatus, OJK is still awaiting trial. This case began with the Capital Adequacy Ratio (CAR) of BPRS Al Hidayah minus $205.61 \%$. must be made healthy by fulfilling a minimum capital of $4 \%$ or Rp. 20.9 billion. 
Because it continues without settlement, BPRS Al Hidayah, whose office is in Ruko Taman Dayu Blok E-1, Pandaan, Pasuruan Regency, was revoked by OJK (Financial Services Authority) dated April 25, 2016.

Above are some examples of fraud cases that occurred in the BPR and BPRS 2012-2017 period

\subsection{Fraud in BPRS and How It Affects Their Roles}

BPRS in development is facing some problems. The problems identified by OJK include: internal BPRS factors such as lack of capital, lack of management, lack of governance, lack of IT system and government policy and external is the lack of knowledge/information and lack of access to credit.

The Indonesian Deposit Insurance Corporation (LPS) announced in the 2016 annual report there were five sharia people's financing banks (BPRS) that had been and were undergoing the process of liquidation from 2009 to 2016. BPR and BPRS problems were generally caused by fraud practices committed by owners, employees or management, as well as bank management that is still not good, especially in terms of risk management, capital and human resource quality (Suheriadi, 2017).

Based on these objectives Islamic banks also have a role in assisting growth MSMEs in Indonesia. There is an increase in people's interest in Islamic banks, especially in the distribution of funds for MSMEs, shows the importance of the presence of Islamic banks (Zamroni, 2013). Research conducted by Maryati (2014) showed that the productive financing carried out by Islamic banks were able to increase the value of production of MSMEs. Role of Islamic Bank which supports the financing of MSMEs able to boost the development of MSMEs through increased production value. Research Faisol (2017) explains that if the Islamic financing increases, the performance of the Silverback MSMEs will increase as well and Islamic finance a significant effect on the welfare of the MSMEs sector.

For more details, previous research related to the role of micro financial institution in assisting MSMEs can be seen in the following table.

Table 1. Previous Studies on MSMEs and Fraud

\begin{tabular}{|c|c|c|c|}
\hline Authors & Subject & Country & Findings \\
\hline $\begin{array}{l}\text { Wang } \\
(2013)\end{array}$ & $\begin{array}{l}\text { Microfinance and } \\
\text { Small and } \\
\text { Medium Enterprises }\end{array}$ & $\begin{array}{l}\text { Taizhou, } \\
\text { China }\end{array}$ & $\begin{array}{l}\text { Microfinance plays a crucial rule in } \\
\text { the revenue and profit growth of } \\
\text { SMEs. }\end{array}$ \\
\hline $\begin{array}{l}\text { Rashidah } \\
\text { Abdul } \\
\text { Rahmana, } \\
\text { Irda Syahira } \\
\text { Khair } \\
\text { Anwarb } \\
\text { (2014) }\end{array}$ & $\begin{array}{l}\text { Effectiveness of fraud } \\
\text { prevention and } \\
\text { detection techniques } \\
\text { in Malaysian Islamic } \\
\text { banks }\end{array}$ & Malaysia & $\begin{array}{l}\text { Findings indicated that the } \\
\text { protection software/application as } \\
\text { the most effective components of } \\
\text { fraud prevention } \\
\text { techniques }\end{array}$ \\
\hline $\begin{array}{l}\text { Hamzah and } \\
\text { Gazali } \\
(2015)\end{array}$ & $\begin{array}{l}\text { Islamic financing and } \\
\text { Micro Enterprises }\end{array}$ & $\begin{array}{l}\text { Labuan, } \\
\text { Malaysia }\end{array}$ & $\begin{array}{l}\text { Both industries (Islamic financing } \\
\text { and Islamic Micro Enterprise) are } \\
\text { insignificant relationship }\end{array}$ \\
\hline $\begin{array}{l}\text { Faisol } \\
(2017)\end{array}$ & $\begin{array}{l}\text { Islamic bank and } \\
\text { Small and }\end{array}$ & $\begin{array}{l}\text { Kediri, } \\
\text { Indonesia }\end{array}$ & $\begin{array}{l}\text { the Islamic bank financing has } \\
\text { significant influence with a positive }\end{array}$ \\
\hline & Medium Enterprises & & $\begin{array}{l}\text { direction on the SMEs } \\
\text { performances }\end{array}$ \\
\hline $\begin{array}{l}\text { Purnamasari } \\
\text { and } \\
\text { Darmawan } \\
(2017)\end{array}$ & $\begin{array}{l}\text { Islamic banking and } \\
\text { Small and } \\
\text { Medium Enterprises }\end{array}$ & Indonesia & $\begin{array}{l}\text { the interaction between SMEs and } \\
\text { Islamic banking is quite close } \\
\text { relatively butneed to be upgraded }\end{array}$ \\
\hline $\begin{array}{l}\text { Yussuf } \\
(2017)\end{array}$ & $\begin{array}{l}\text { Islamic banking and } \\
\text { Small and } \\
\text { Medium Enterprises }\end{array}$ & Nairobi & $\begin{array}{l}\text { Islamic banking helps SMEs to } \\
\text { grow financially which } \\
\text { enhancestheir financial } \\
\text { performance. The study also } \\
\text { concludes that Islamic banking } \\
\text { affects the growth of SMEs. }\end{array}$ \\
\hline
\end{tabular}




\begin{tabular}{|c|c|c|c|}
\hline $\begin{array}{l}\text { Suharto and } \\
\text { Faisal } \\
\text { (2017) }\end{array}$ & $\begin{array}{l}\text { Islamic banking and } \\
\text { Small and } \\
\text { Medium Enternrises }\end{array}$ & Indonesia & $\begin{array}{l}\text { Islamic Bank has various barriers, } \\
\text { in developing MSMEs in Indonesia }\end{array}$ \\
\hline $\begin{array}{l}\text { Purwanto } \\
\text { and } \\
\text { Andriani } \\
\text { Kusuma } \\
(2019)\end{array}$ & $\begin{array}{l}\text { Patterns of Fraud } \\
\text { Operating Mode of } \\
\text { Financing and Efforts } \\
\text { to Minimize the } \\
\text { Shortcoming in BPRS } \\
\text { X }\end{array}$ & Indonesia & $\begin{array}{l}\text { The results showed that there were } \\
\text { elements of BPRS X who had } \\
\text { practiced fraud starting from the } \\
\text { submission stage, data analysis and } \\
\text { approval in the form of falsifying } \\
\text { documents by conditioning the } \\
\text { submission so that they could pass } \\
\text { the financing so that there were } \\
\text { mask credit findings, credit in the } \\
\text { name. }\end{array}$ \\
\hline
\end{tabular}

MSMEs that receive funding from Islamic banks to support MSMEs in the ability to provide capital, so that productivity, revenue, and profit increases, resulting in increased performance.

The Association of Bank Rakyat Indonesia (Perbarindo) reports that the performance of the rural bank credit (BPR) and Islamic BPR (BPRS) industry is still growing well until the first semester of 2018. This can be seen from the growth of lending and third party funds (DPK). Perbarindo General Chairman Djoko Suyanto explained, as of July 2018 the number of loans channeled by BPR and BPRS reached Rp. 95 trillion, dominated by loans for MSMEs.

This figure grew $8.59 \%$ compared to the same period the previous year. "Success in lending reflects the industry of BPR and BPRS having products and services that can be well received by the community," Djoko said. Meanwhile, in terms of collecting deposits, the amount of savings in July 2018, reached Rp28 trillion, up $14.23 \%$ compared to the position a year earlier.

The same is true for the deposits side, which recorded growth reaching $8.99 \%$ to IDR 60 trillion in July 2018. Also, the BPR and BPRS industries have served 17 million customers, consisting of 4 million debtors with an average loan IDR 27 million. As for the number of depositors as many as 600,000 accounts with an average deposit of Rp102 million and savers of 12.4 million accounts with an average savings of Rp2 million.

Drs.H. Syukri Iska, M.Ag, in a study revealed that there were problems related to Islamic purity in operating in Islamic banks, margin / mark up on murabahah (buying), mudharabah contract on savings where customers could withdraw their funds at any time (on-call) whereas it has not been produced (tasharruf) by the bank. While Prof. Dr. H. Amir Syarifuddin assessed that the application of mudharabah and murabaha contracts to bank activities raises things that can lead to subhat and also the practice of usury/rent.

In the implementation of these contracts in Islamic banks, there are additional actors of contract, namely banks as intermediaries. then the age of Islamic banking in Indonesia is approximately 17 years which is a relative short age, and Islamic banks in carrying out their operations are still very few human resources who have a background in sharia education.

Islamic banks must be able to provide optimal benefits to the community and the roles and responsibilities of Islamic banks as Islamic financial institutions and ensure that all activities carried out by Islamic banks are by following sharia principles (Hameed, 2004). Also, the biggest challenge that must be faced is to maintain the image and reputation in the eyes of customers to maintain customer trust and loyalty to Islamic banks (Falikhatun and Assegaf, 2012).

As of 2017 there are 166 BPRS operating in Indonesia (Financial Services Authority 2017). A number of research on the financial performance of BPRS show that most of them have inefficient financial performance (Chou \& Buchdadi, 2016; Muhari \& Hosen, 2014 ; Naufal \& Firdaus, 2017; Handayani, 2013).

Data submitted by OJK (2017) also shows that the amount of financing distributed by BPRS exceeds the amount of funds collected, while the level of their profitability tends to decrease. This condition shows a number of problems faced by BPRS in Indonesia from 2007 to 2016.

Indonesia Deposit Insurance Corporation in its 2017 annual report announces that as many as five BPRS, out of a total of 85 rural credit banks (BPR), have been and are undergoing a liquidation process from 2009 to 2017. 
The operandi pattern of fraud that occurs in the distribution of bank financing as well as efforts to minimize fraud that occurs in the distribution of Islamic banking financing (Purwanto, 2019).

The thing that often happens in BPRS is that the procedure for granting loans is not in accordance with the procedure, (Hutauruk 2014), the fraudulent modus operandi is played (Budianto 2013), there is a problem that impedes the smooth running of the credit process, which is inconsistent in carrying out procedures for granting credit, (Syafriansyah, 2015), fraudulent acts committed by bank employees can occur because of the behavior and moral honesty that is caused by occupational crime , (Holtfrefer, 2003).

In assisting MSMEs financing arise fraud committed by human resources from lower levels to top management, this has a negative impact on the financial condition of the BPRS so that losses can later be liquidated.

Impacts of BPRS being liquidated on Shareholders and Management (Directors and Commissioners) becomes List of Despicable Person and for other employees it will be a bad record, if there is a criminal element will be further processed in the police.

If many BPRS are liquidated, it will hamper assisting in financing, business assistance, training and network of marketing to MSMEs which in the end will not be able to grow and cause the development of the real sector to stagnate and also the absorption of labor becomes small.

\section{Conclusion}

The role of MSMEs in the Indonesian economy is so strategic, it can be seen from the Financial Crisis in 1998, MSMEs businesses were relatively more resilient than large-scale enterprises. Based on the discussion above, it can be concluded that the role of BPRS is vital to help the development of MSMEs so that their businesses are growth.

In assisting MSMEs in terms of financing, BPRS face problems in interpreting sharia rules from many fraud cases that occur on average because of fraud (dispute issues, fraud) because the owner or management of the BPRS commits fraud and also their workers.

Most of the BPRS liquidated are caused by fraud, not because of business competition.

The causes of fraud in financing are many factors, including engineering of credit issuance, private credit (which receives credit, not those who apply for credit), fictitious credit (credit is never received by the customer as written in the contract) and twice credit for the same customer.

This fraud made the Sharia Rural Bank suffer losses and could eventually be liquidated so that capital assistance to the MSMEs was reduced and caused the MSMEs could not grow nor did the real sector stagnate and absorb the labor force to a small extent.

\section{References}

[1]Association of Certified Fraud Examiners (ACFE).: Fraud Prevention and Detterence, Fraud Examiners Manual, International Edition (FPD). (2014)

[2]Budianto, A.: Reviewing corporate crime in banking in the Indonesian banking system. Pelita Harapan University Karawaci. (2013)

[3]Chou, T., \& Buchdadi, A. D.: Bank performance and its underlying factors : a study of rural banks in Indonesia. 5(3), 55-63. Accounting and Finance Research. https://doi.org/10.5430/afr.v5n3p55. (2016)

[4]Faisol.: Islamic bank financing and it's impact on small medium enterprise's performance. Volume 16(1) Page 13-24. Journal Etikonomi. (2017)

[5]Financial Services Authority Regulation (POJK) Number 11 / POJK.03 / 20162016 concerning minimum capital requirements for commercial banks. 2 February 2016. Retrieved from https://www.ojk.go.id/en/kanal/perban/regulations/ regulations-ojk/Documents/Pages/pojk11-obligations - provision - capital - minimum - banks - general / COPY - POJK. 11\% 20 Conversion\% 20KPMM\% 20FINALE.pdf.

[6]Financial Fervices Authority.: Sharia Banking Statistics January 2017. 23 March 2017. Retrieved from https://www.ojk.go.id/en/kanal/syariah/data-dan-statistik/ Statistics-Sharia-Banking / Pages / StatisticsSharia-Banking- - January-2017.aspx. (2017)

[7]Handayani, I.: Efficiency analysis of islamic sharia financing banks (BPRS) in Indonesia with the Data Envelopment Analysis (DEA) Approach. Essay. (2016) 
[8]Islamic Economics and Banking Studies, Faculty of Islamic Religion, Yogyakarta Muhammadiyah University. Yogyakarta.

[9]Holtfreter, K. Is occupational fraud typical white-collar crime? A comparison of individual and organizational characteristics. Journal of Criminal Justice 33. (2003)

[10]Hutauruk, R. P. S., S.: Analysis of procedures for granting credit to PT.Bank Cimb Niaga Laju Tebing Tinggi. Accounting Scientific Journal Changes, StEI Bina Karya Tebing Tinggi. (2014)

[11]Kompas.com with the title "OJK Reveals Cases of Misappropriation in BPR KS Bali", https://ekonomi.kompas.com/read/2018/04/25/111043226/ojk- reveal-cases-fraud-in-bpr-ks- Bali

[12]Lembaga Penjamin Simpanan:. Deposit Insurance Corporation - Liquidated Banks. Lps.Go.Id. Retrieved from http://www.lps.go.id/bank-that-condidated. (2018)

[13]Muhari, S., \& Hosen, M. N.: BPRS efficiency levels in Indonesia: Comparison of the SFA Method with the DEA and its relationship with CAMEL. 18 (2), 307-328. Journal of Finance and Banking. Retrieved from https://media.neliti.com/media/ publications / 107775-ID-level-efficiency-bprs-inindonesia-Perb.pdf. (2014)

[14]Naufal, F. M., \& Firdaus, A.: Efficiency Analysis of the Jabodetabek Regional Islamic Sharia Bank (BPRS) with the two stage Data Envelopment Analysis (DEA) approach. 5 (2), 196-220. EQUILIBRIUM: Shariahi Syariah Economic Journal. Retrieved from https://www.researchgate.net/publication/325438991_Bank_Enfficiency_Analysis_DeaFinance_Syariah_ BPRS_World_Jabodetabek_with_Approaches_Two_Stage_Data_Envelopment_Analysis_Dea. (2017) [16]Suheriadi. These are 5 problems that internally undermine BPR Infobanknews. Retrieved March 25, 2019, from http://infobanknews.com. (2017)

[17]Surat Edaran Bank Indonesia (SEBI) Nomor 9/29/DPbS /2007 Regarding the Rating System for the Health of Rural Banks Based on Sharia Principles. December 7, 2007. Retrieved from https://www.ojk.go.id/en/kanal/syariah/ regulation / regulations-banking-sharia-pbi-and-sebi / Pages / circular-bank-indonesia-number- 9-29-dpbs-3.aspx

[18]Syafriansyah, M.: Analysis of systems and procedures for providing credit to sentosa savings and loans cooperatives in Samarinda. E Journal of Business Administration. (2015)

[19]Wang, Xitian.: The impact of microfinance on the development of small and medium enterprises: the case of Thaizhou, Cina. The John Hopkins University, Baltimore, MD, USA. (2013)

[20]Yussuf, A.: Effect of Islamic Banking on growth of small medium enterprises in Nairobi : a case study of first community bank, United State International University, Africa. (2017) 